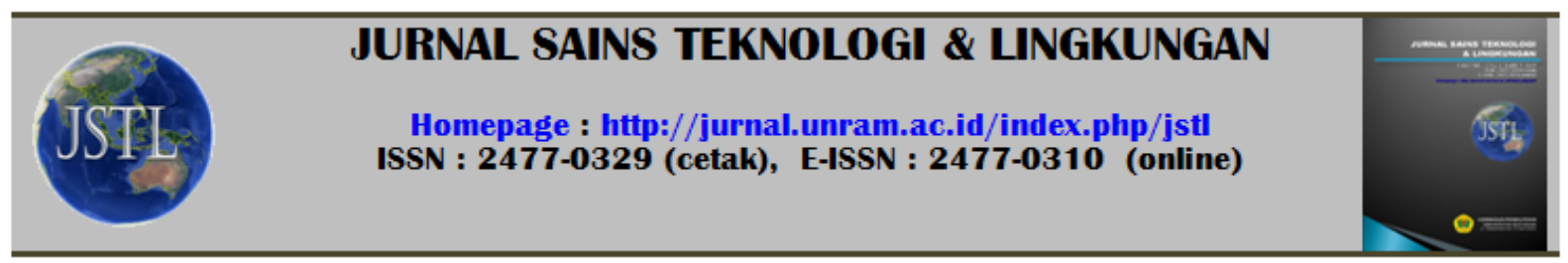

\title{
EVALUASI KEKUATAN ELEMEN STRUKTUR KOLOM MENGGUNAKAN PERALATAN NDT
}

$\left.{ }^{1}\right)$ Edy, ${ }^{1}$ ) Akmaluddin, $\left.{ }^{1}\right)$ Ni Nyoman Kencanawati $\left.{ }^{1}\right)$ Jurusan Teknik Sipil, Program Pascasarjana, Universitas Mataram

\begin{tabular}{l} 
Kata kunci : \\
\hline kolom, cepat \\
rambat \\
gelombang, \\
tulangan, selimut, \\
NDT.
\end{tabular}

\begin{abstract}
Abstrak
Ketidaksesuaian saat pelaksanaan dan perencanaan yang telah dibuat terkait bahan dan fungsi bangunan mengakibatkan elemen struktur bangunan tersebut dipertanyakan kinerjanya. Untuk menjawab keraguan tersebut maka diperlukan suatu evaluasi guna memastikan kekuatan elemen struktur tersebut. Penelitian ini dimaksudkan untuk membangun model yang dapat memprediksi kuat tekan, diameter tulangan dan tebal selimut beton berdasarkan bacaan peralatan NDT yang selanjutnya digunakan sebagai alat analisa/evaluasi kapasitas tahanan struktur kolom. PUNDIT dan Bartracker Covermeter merupakan alat NDT utama selain peralatan standar yang digunakan dalam penelitian ini. Empat seri pengujian pendahuluan yang direncanakan. Seri I menggunakan benda uji silinder diameter $150 \mathrm{~mm}$ dengan tinggi $300 \mathrm{~mm}$ dan kubus 200x200x200 mm masingmasing 9 buah, yang mewakili 3 jenis mutu beton yang dibebani sampai hancur. Seri II merupakan pengujian pada 9 buah kubus beton dengan 3 variasi mutu. PUNDIT diaplikasikan pada peningkatan beban menerus secara bertahap yaitu 25\%, 50\%, 75\% dan 100\%. Seri III 27 buah kubus terdiri atas 9 buah yang mewakili 3 mutu beton diuji pada beban yang ditinjau yaitu $25 \%, 50 \%$ dan $75 \%$ hingga mencapai beban hancur $100 \%$. Seri IV terdiri atas 1 kubus styrofoam ukuran 360x220x190 mm yang berisikan tulangan yang dapat diatur diameter dan posisi penempatannya. Seri ini dimaksudkan untuk memprediksi diameter tulangan dan tebal selimut beton aktual dilapangan. Selanjutnya pengujian untuk evaluasi kekuatan elemen struktur kolom menggunakan benda uji kolom 140x140x1500 mm sebanyak 6 buah. Hasil menunjukkan bahwa aplikasi PUNDIT menghasilkan kuat tekan material kolom bervariasi sebesar 27, 29 dan $30 \mathrm{MPa}$ untuk mutu bahan kolom yang direncanakan masing-masing 20, 30, dan $40 \mathrm{MPa}$. Pada aplikasi Bartracker Covermeter diperoleh rasio diameter tulangan dan tebal selimut terhadap nilai aktualnya sebesar 0,970 dan 1,010 dengan tingkat kesalahan deteksi sebesar 5,67\% dan -1,06\%. Rasio kapasitas tahanan penampang kolom Po sebesar 0,908 terhadap kapasitas Po aktual.
\end{abstract}

Key words : column, velocity, rebar diameter, concrete cover, NDT .

\begin{abstract}
Differences between design and construction of materials and building function led to structural elements of building performance are questionable. In order to answer these doubt, evaluations to ensure the strength of those structural elements are needed. The aim of this study is to build models that can predict the compressive strength, the bar diameter and concrete cover based on NDT equipment. The models were then used as tools in analysis and evaluation of resistant capacity of structural column elements. PUNDIT and Bartracker Covermeter were the main NDT apparatus in addition to the standard equipment used in this study. Four series of preliminary test were employed. Series I consisted 9 units of $150 \mathrm{~mm}$ diameter and $300 \mathrm{~mm}$ height of cylindrical test specimen and $200 \times 200 \times 200 \mathrm{~mm}$ concrete cube, representing 3 types of concrete qualities loaded until crushed were considered. Series II were test of the 9 units of concrete cubes with 3 variations. PUNDIT was applied to the specimen with given continuous gradually load incremental of 25\%, 50\%, 75\% and 100\%. Series III, 27 concrete cubes of nine units which represented 3 concrete strenght were tested at prefferred load of 25\%, 50\% and $75 \%$ until each of the percentage load reach their maximum load. Series IV consisted of a $360 \times 220 \times 190 \mathrm{~mm}$ styrofoams cube, containing reinforcement with adjustable diameter and placement positions. This series was intended to predict existing reinforcement diameter and concrete cover thickness in the field. Furthermore, testing to evaluate strength capacity of columns elements were used 6 column test specimen of 140x140x1500 mm. Results showed that PUNDIT application gave column material compressive strength varies of 24, 27 and $28 \mathrm{MPa}$ for column material strenght required of 20, 30 and $40 \mathrm{MPa}$, respectively. Whilst on the application of Bartracker Covermeter produced bar diameter and cover thickness ratio to the actual values of 0.970 and 1.010 with detection error rate of $5.67 \%$ and $-1.06 \%$ respectively. Ratio of column section capacity, Po, obtained was 0.908 of the column actual value.
\end{abstract}

(C)2015 Universitas Mataram

\footnotetext{
Alamat koresponden penulis: E-mail : edymts13@gmail.com
} 


\section{PENDAHULUAN}

Gedung terdiri dari beberapa elemen struktur utama seperti kolom, balok dan pelat lantai. Elemen-elemen struktur tersebut didesain sedemikian rupa untuk memenuhi syarat kekuatan dan syarat layan. Meskipun telah direncanakan dengan baik terkadang dalam pelaksanaannya terdapat perubahan baik dalam penerapan mix design maupun saat proses pengecoran. Perubahan diameter tulangan serta penempatannya berpengaruh langsung terhadap kinerja elemen struktur beton bertulang.

Bentuk lain ketidaksesuaian perencanaan adalah perubahan atau pengalihan fungsi bangunan. Hal ini berpeluang terjadinya pembebanan berlebihan (overload). Ketidaksesuaian saat pelaksanaan maupun setelah pelaksanaan dengan perencanaan yang telah dibuat terkait bahan dan fungsi bangunan mengakibatkan elemen struktur bangunan tersebut dipertanyakan kinerjanya.

Diperlukan suatu evaluasi untuk memastikan kekuatan elemen struktur terutama material beton dan tulangannya. Pada tulangan khususnya, diameter dan posisi penempatannya memiliki pengaruh yang signifikan. Untuk mengetahui tingkat kerusakan dan mengembalikan kinerja struktur diperlukan evaluasi dan analisis dengan pengujianpengujian yang tidak mengganggu kondisi eksistingnya.

Untuk itu pengujian menggunakan metode nondestructive test (NDT) cocok untuk menjawab persoalan diatas. Saat ini peralatan pengujian metode NDT ini tersedia dalam banyak jenis antara lain Hammer Test, UPV, Resipod, Crack Detector, uji karbonasi, Radiografi, Covermeter dan Rebar Locator.

Mengingat struktur kolom adalah batang vertikal dari rangka struktur yang memikul beban dari balok (SNI-03-2847-2002) maka dalam penelitian ini elemen struktur tekan atau kolom menjadi fokus kajian. Kondisi aktual (eksisting) struktur kolom di representasikan dengan kolom yang dibebani di laboratorium, diuji dengan peralatan PUNDIT dan Bartracker Covermeter. Pengujian pendahuluan untuk membangun model interpretasi kuat tekan beton dari alat PUNDIT (Anonim, 2007a) dan interpretasi diameter tulangan serta tebal selimut serta tingkat kesalahan deteksi dari alat Bartracker Covermeter.
Tujuan utama dalam penelitian ini adalah untuk memperoleh data kuat tekan, diameter tulangan, spasi tulangan dan tebal selimut pada kolom berdasarkan model korelasi yang dibangun. Data yang diperoleh digunakan pada evaluasi kapasitas tahanan penampang kolom untuk mengetahui apakah struktur tersebut masih memiliki kemampuan menerima beban sesuai kondisi saat ini.

Akmaluddin (2008) dalam studinya, kuat tekan beton diestimasi dari informasi korelasi nilai modulus elastisitas dan kuat tekan. Nilai modulus elastis yang diperoleh dari peralatan NDT dikenal sebagai modulus elastis dinamis $\left(\boldsymbol{E}_{\boldsymbol{d}}\right)$ sedangkan modulus elastisitas yang diperoleh dari pengujian destruktif dikenal sebagai modulus elastis statis $\left(\boldsymbol{E}_{\boldsymbol{c}}\right)$. Korelasi $\boldsymbol{E}_{\boldsymbol{c}}$ dan $\boldsymbol{E}_{\boldsymbol{d}}$ dibangun dan dikonversi menjadi nilai kuat tekan, hasilnya menunjukkan bahwa terdapat kesamaan tren antara nilai modulus elastisitas yang diperoleh dengan formula yang telah dibangun BS-1881 (British Standard, 1988).

Hariwarsianto, dkk (2008) meneliti tentang letak dan ukuran diameter tulangan dengan peralatan Rebar Locator merek Profometer. Hasil yang diperoleh adalah dapat mendeteksi letak, jarak dan pengukuran diameter tulangan pelat lantai. Hasil pengukuran tersebut dapat ditentukan kebutuhan tulangan minimum untuk memikul beban rencana. Peralatan ini dapat memprediksi kondisi tulangan dalam beton. Penggunaan alatalat pengukur jenis ini memerlukan ketelitian dan kehandalan khusus dalam pengoperasiannya.

Sivasubramanian, dkk (2013) meneliti tentang deteksi tebal selimut dan diameter tulangan pada beton mutu tinggi dengan peralatan Covermeter (Profometer) dengan probe kecil dan besar. Hasil identifikasi kesalahan deteksi tebal selimut adalah semakin besar ketebalan selimut menunjukkan semakin besar persentase tingkat kesalahan deteksi. Penelitian ini sangat penting bagi praktisi teknik sipil untuk memahami keandalan hasil yang diperoleh dalam menggunakan teknologi ini. Hasil ini diperoleh dari kondisi laboratorium dan hasilnya dapat lebih diandalkan dari kondisi lapangan.

\section{METODOLOGI PENELITIAN}

Penelitian ini dilakukan di Laboratorium Struktur dan Bahan Jurusan Teknik Sipil Fakultas Teknik Universitas Mataram, pada 
bulan Agustus sampai dengan bulan Oktober 2015. Peralatan yang dipergunakan dalam penelitian ini adalah mesin uji tekan (Compression Testing Machine) merek Controls Milano yang bersifat merusak benda uji. Peralatan yang bersifat tidak merusak benda uji (Non Destructive Test) menggunakan PUNDITplus buatan CNS FARNELL Inggris, Bartracker Covermeter model 58-E6102 merek Controls. Adapun aplikasi peralatan tersebut terlihat seperti pada Gambar 2 berikut :

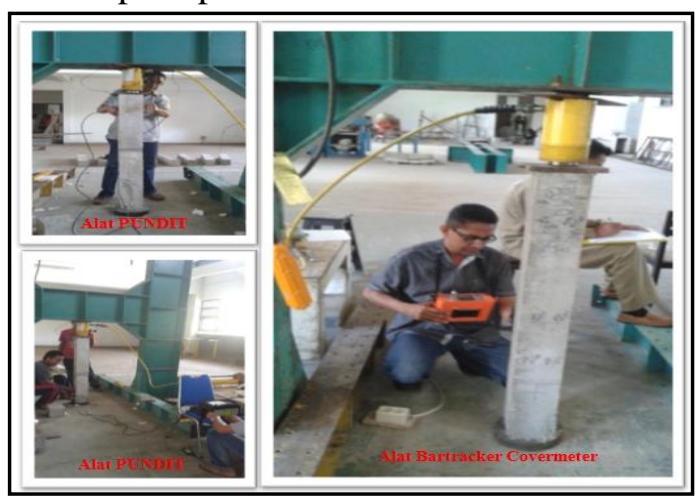

Gambar 1. Aktifitas Pengujian Kolom dengan PUNDIT dan Bartracker

Tiga variasi mutu beton direncanakan dengan menggunakan bahan campuran beton terdiri dari semen Portland type I, agregat kasar, agregat halus dan air jernih. Agregat kasar dan halus berasal dari Pringgabaya, Lombok Timur. Adapun komposisi campuran untuk memperoleh variasi kuat tekan tersebut adalah Tabel 1 berikut :

Tabel 1. Rancangan Komposisi CampuranBeton
\begin{tabular}{|c|c|c|c|c|c|c|}
\hline No & $\begin{array}{c}f_{c}(M P a) \\
\text { rencana }\end{array}$ & FAS & $\begin{array}{c}\text { Semen } \\
\left(\mathrm{kg} / \mathrm{m}^{3}\right)\end{array}$ & $\begin{array}{c}\text { Air } \\
\left(\mathrm{kg} / \mathrm{m}^{3}\right)\end{array}$ & $\begin{array}{c}\text { Pasir } \\
\left(\mathrm{kg} / \mathrm{m}^{3}\right)\end{array}$ & $\begin{array}{c}\text { Kerikil } \\
\left(\mathrm{kg} / \mathrm{m}^{3}\right)\end{array}$ \\
\hline$(1)$ & $(2)$ & $(3)$ & $(4)$ & $(5)$ & $(6)$ & $(7)$ \\
\hline 1 & 20 & 0,59 & 347 & 205 & 745 & 1118 \\
\hline 2 & 30 & 0,53 & 387 & 205 & 729 & 1094 \\
\hline 3 & 40 & 0,45 & 456 & 205 & 702 & 1053 \\
\hline
\end{tabular}

\section{Benda Uji}

Benda uji yang digunakan sebanyak 61 buah terdiri dari 9 buah silinder diameter $150 \mathrm{~mm}$ dan tinggi $300 \mathrm{~mm}, 45$ buah kubus 200x200x200

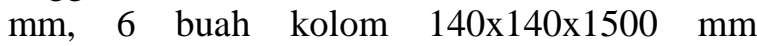
bertulangan $4 \varnothing 8 \mathrm{~mm}$ dengan sengkang $\varnothing 6-150$ $\mathrm{mm}$. Benda uji kubus styrofoam 360x220x190 $\mathrm{mm}$ sebanyak 1 buah untuk memvariasikan diameter tulangan, tebal selimut dan spasi tulangan. Variasi diameter tulangan meliputi diameter 8, 10, 12, 16 dan $19 \mathrm{~mm}$ dengan tebal selimut $\left(d^{\prime}\right)$ 20, 30, 40, 50 dan $60 \mathrm{~mm}$ dan spasi tulangan $(s=0),(s=40)$, dan $(\mathrm{s}=80) \mathrm{mm}$.
Gambar 1 memperlihatkan bentuk benda uji dimaksud.

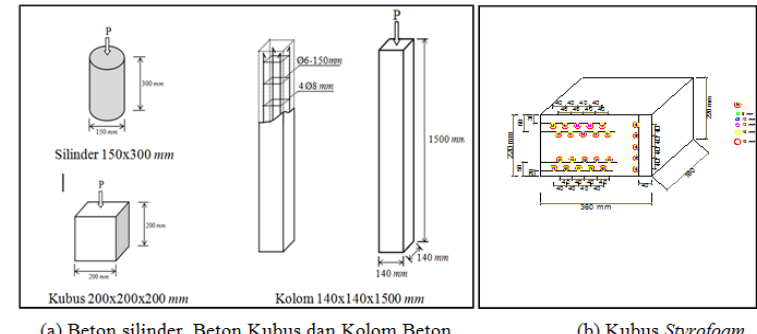

\section{Metode Pengujian}

Pengujian benda uji dilakukan di Laboratorium dibagi dalam 5 (lima) seri pengujian. Seri I merupakan pengujian pendahuluan yang dimaksudkan untuk mengkonversi nilai benda uji kubus terhadap silinder, hal ini dimaksudkan untuk memudahkan analisis hasil pada benda uji seri berikutnya yang semuanya dipertimbangkan berbentuk kubus guna kemudahan aplikasi alat. Seri II dan III merupakan pengujian pada benda uji kubus beton dengan variasi tahap pembebanan untuk membangun model empiris kuat tekan beton eksisting. Sedangkan Seri IV menggunakan benda uji kubus Styrofoam sebagai media pengaturan/penempatan baja tulangan sehingga model empris diameter tulangan dan tebal selimut dapat dibangun. Seri $\mathrm{V}$ adalah pengujian seri terakhir berupa kolom beton bertulang yang mewakili kondisi eksisting komponen tekan struktur bangunan dilapangan. Model-model yang diperoleh pada seri-seri sebelumnya diaplikasikan pada seri pengujian ini. Adapun uraian tata cara pengujiannya sebagai berikut :

\section{Seri I (uji pendahuluan)}

Pengujian seri I terdiri dari benda uji masingmasing 9 buah silinder dan kubus beton. Benda uji ditekan menggunakan peralatan mesin uji tekan CTM mengacu pada SNI 03-1974-1990. Pembebanan diberikan mulai dari 0 hingga mencapai beban maksimal (benda uji hancur). Hasil pengujian dari dua jenis benda uji ini selanjutnya dikonversi yaitu nilai kuat tekan kubus $\left(f_{c k}\right)$ menjadi nilai kuat tekan silinder $\left(f_{c}\right)$.

\section{Seri II dan Seri III}

Pengujian seri II terdiri atas 9 buah kubus beton yang diuji secara bersamaan antara DT (menggnakan CTM) dan NDT (menggunakan PUNDIT). Pembebanan diberikan menerus secara bertahap mulai dari kurang lebih $25 \%$ 
dari perkiraan beban maksimum, kemudian $50 \%, 75 \%$ dan $100 \%$ (hancur). Pengujian seri III identik dengan Seri II hanya berbeda pada pola pembebanannya. Benda uji sebanyak 27 buah kubus dibutuhkan. Pembebanan diberikan hanya dua tahap yaitu pada beban yang ditinjau dan beban maksimal seperti beban tinjauan $25 \%$ dan $100 \%$, beban $50 \%$ dan $100 \%$, beban $75 \%$ dan $100 \%$. Nilai kuat tekan kubus dan cepat rambat gelombang diperoleh dari seri pengujian ini.

\section{Seri IV}

Pengujian seri IV menggunakan benda uji kubus styrofoam sebagai media pengaturan pola spasi tulangan dan tebal selimut beton. Bahan styrofoam dipilih guna memudahkan pengaturan penempatan baja tulangan dan juga bahan ini bebas dari kandungan bahan yang sensitive terhadap magnet. Alat Bartracker Covermeter menggunakan probe Standard mengacu pada SE-M-21-2015. Pola variasi diameter tulangan $\left(d_{b}\right)$, tebal selimut $\left(d^{\prime}\right)$ dan jarak/spasi $(s)$ tulangan disajikan dalam Tabel 2 berikut :

Tabel 2 Pola Variasi Benda Uji Bartracker Covermeter

\begin{tabular}{|c|c|c|c|c|c|c|c|c|c|}
\hline \multicolumn{10}{|c|}{$d b(\mathrm{~mm})$} \\
\hline \multicolumn{2}{|c|}{8} & \multicolumn{2}{|c|}{10} & \multicolumn{2}{|c|}{12} & \multicolumn{2}{|c|}{16} & \multicolumn{2}{|c|}{19} \\
\hline$d^{\prime}(\mathrm{mm})$ & $s(\mathrm{~mm})$ & $d^{\prime}(\mathrm{mm})$ & $s(\mathrm{~mm})$ & $d^{\prime}(\mathrm{mm})$ & $s(\mathrm{~mm})$ & $d^{\prime}(\mathrm{mm})$ & $s(\mathrm{~mm})$ & $d^{\prime}(\mathrm{mm})$ & $s(\mathrm{~mm})$ \\
\hline \multirow{3}{*}{20} & 0 & \multirow{3}{*}{20} & 0 & \multirow{3}{*}{20} & 0 & \multirow{3}{*}{20} & 0 & \multirow{3}{*}{20} & 0 \\
\hline & 40 & & 40 & & 40 & & 40 & & 40 \\
\hline & 80 & & 80 & & 80 & & 80 & & 80 \\
\hline \multirow{3}{*}{30} & 0 & \multirow{3}{*}{30} & 0 & \multirow{3}{*}{30} & 0 & \multirow{3}{*}{30} & 0 & \multirow{3}{*}{30} & 0 \\
\hline & 40 & & 40 & & 40 & & 40 & & 40 \\
\hline & 80 & & 80 & & 80 & & 80 & & 80 \\
\hline \multirow{3}{*}{40} & 0 & \multirow{3}{*}{40} & 0 & \multirow{3}{*}{40} & 0 & \multirow{3}{*}{40} & 0 & \multirow{3}{*}{40} & 0 \\
\hline & 40 & & 40 & & 40 & & 40 & & 40 \\
\hline & 80 & & 80 & & 80 & & 80 & & 80 \\
\hline
\end{tabular}

\section{Seri V}

Benda uji kolom beton bertulang sebanyak 6 buah digunakan. Dibebani sentris pada penampang kolom dengan beban menerus secara bertahap mulai $25 \%$, 50\% sampai beban $75 \%$ dari beban maksimal (beban ultimit hasil perhitungan). Pembacaan alat PUNDIT dan Bartracker Covermeter dilakukan pada saat tahapan pembebanan tersebut.

\section{Analisis Data}

Data yang diperoleh dari pengujian peralatan DT dan NDT dianalisis untuk membangun model hubungan antara hasil uji DT dan NDT maupun hubungan antar parameter dalam satu jenis pengujian. Alat bantu analisis regresi linier sederhana menggunakan Excel dari MS office. Parameter yang ingin dicari (variabel terikat) diletakkan pada sumbu-ordinat (sumbu-y) sedangkan variabel bebas diletakkan pada sumbu-aksis (sumbu-x) yang selanjutnya akan menghasilkan persamaan empiris. Berikut ini adalah model-model hubungan yang dibangun dalam studi ini: (a) Prediksi kuat tekan $\left(f^{\prime}{ }_{c}\right)$ diperoleh dari model hubungan antara nilai $f_{c}$, dan $v$; (b) Prediksi diameter tulangan $\left(d_{b}\right)$ diperoleh dari model hubungan antara $d_{b}$ aktual dan $d_{b}$ hasil pembacaan alat; (c) Tebal selimut $(d$ ') dipredisi dari model hubungan antara $d$ ' aktual dan $d$ ' hasil pembacaan alat yang dibangun.

\section{HASIL DAN PEMBAHASAN}

\section{Hubungan Kuat Tekan $\left(f_{c}^{\prime}\right)$ dengan Cepat Rambat Gelombang (v)}

Gambar 2 dibawah ini menyajikan hubungan antara $f^{\prime}{ }_{c}$ dan $v$ dari pengujian kubus pada kondisi pembebanan $0 \%$ (belum dibebani), $25 \%, 50 \%$ dan $75 \%$.

Dari gambar tersebut tampak bahwa secara umum semakin besar nilai $v$ maka nilai $f_{c}$ ' beton semakin meningkat atau $f_{c}^{\prime}$ berbanding lurus dengan $v$. Terlihat juga bahwa kemiringan garis (slope) pada gambar tersebut semakin menurun dengan bertambahnya persentase beban yang bekerja. Hal ini juga terlihat pada persamaanpersamaan berikut ini yang mana koefisien $v$ semakin mengecil dengan meningkatnya pembebanan.

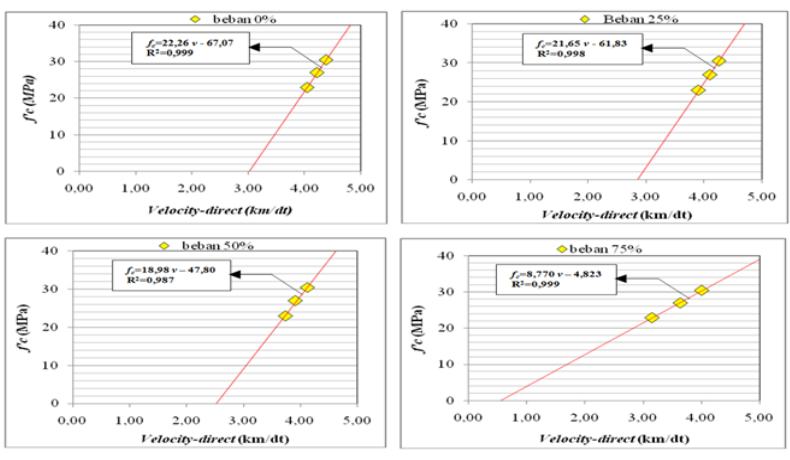

Gambar 3. Grafik Hubungan Nilai $f^{\prime} c$ dan $v$ Pada Berbagai Persentase Beban

Adapun persamaan-persamaan tersebut untuk pembebanan 0\%, 25\%, 50\% dan 75\% masingmasing disajikan seperti Persamaan (1), (2), (3) dan (4) berikut :

$f^{\prime}{ }_{c}=22,26 v-67,07$. 


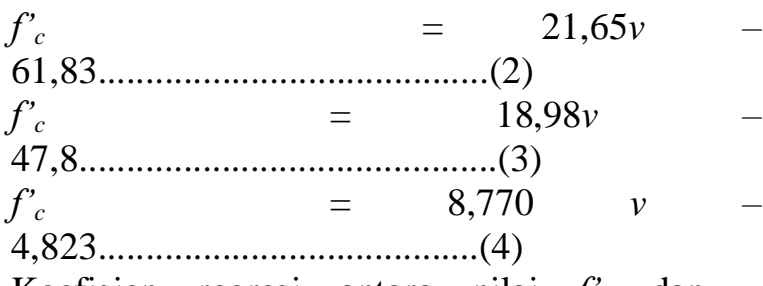

Koefisien regresi antara nilai $f_{c}{ }_{c}$ dan $v$ menunjukkan hubungan korelasi yang kuat ditandai dengan korelasi regresi (r) masingmasing sebesar 0.999, 0.998, 0.987 dan 0.999 untuk Persamaan (1), (2), (3) dan (4). Koefisien determinasi $\left(\mathrm{r}^{2}\right)$ masing-masing persamaan tersebut sebesar 0.9980, 0.9960, 0.9742 dan 0.9980. Koefisien tersebut memperlihatkan tingkat kesalahan prediksi sebesar (100\%$99.80 \%)=0.20 \%,(100 \%-99.60 \%)=0.40 \%$, $(100 \%-97.42 \%)=2.58 \%$ dan $(100 \%-99.80 \%)=$ $0.20 \%$.

\section{Hubungan Diameter Tulangan Aktual $\left(d_{b a}\right)$ dan Diameter Tulang Hasil Ukur $\left(d_{b u}\right)$}

Hubungan diameter tulangan aktual $\left(d_{b a}\right)$ dan diameter tulangan hasil pengukuran $\left(d_{b u}\right)$ dengan variasi jarak tulangan $(s)$ disajikan pada Gambar 3.

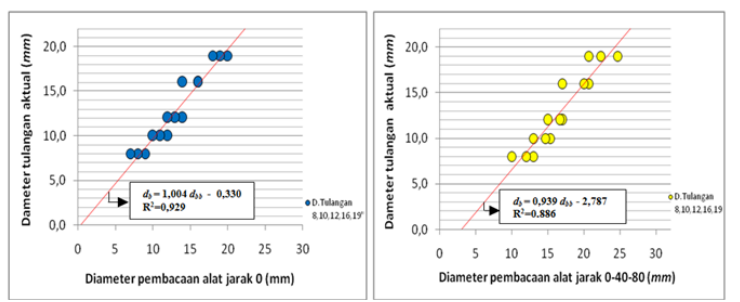

Gambar 4. Diameter Tulangan dengan Variasi Jarak $(s)$

Dari gambar diatas tampak bahwa semakin besar nilai $d_{b a}$ maka semakin besar pula $d_{b u}$. Model persamaan linier dibangun berdasarkan data yang disajikan pada Gambar 3 diatas masingmasing untuk tulangan tunggal $(s=0)$ dan tulangan parallel ( $\mathrm{s}=40$ dan $80 \mathrm{~mm}$ ) masingmasing sebagai Persamaan (5) dan Persamaan (6) berikut :

$$
\begin{aligned}
& d_{b}=1,004 \quad\left(d_{b u}\right) \quad- \\
& 0,330 \ldots \ldots \ldots \ldots \ldots \ldots \ldots \ldots(5) \\
& \begin{array}{llll}
d_{b} & =0,939 & \left(d_{b u}\right) & -2,787
\end{array} \\
& \text {..(6) }
\end{aligned}
$$

Persamaan (5) dan (6) terlihat bahwa koefisien regresi antara nilai $d_{b}$ dan $d_{b u}$ menunjukkan hubungan korelasi yang kuat ditandai dengan korelasi regresi (r) masing-masing sebesar 0,929 dan 0,886. Koefisien determinasi $\left(r^{2}\right)$ sebesar 0,8630 dan 0,8750 menunjukkan tingkat kesalahan prediksi sebesar $(100 \%-86,30 \%)=$ $13,70 \%$ dan $(100 \%-78,50 \%)=21,50 \%$.

\section{Hubungan Tebal Selimut Aktual $\left(d^{\prime}{ }_{a}\right)$ dan Tebal Selimut Ukur $\left(\boldsymbol{d}_{\boldsymbol{u}} \boldsymbol{)}\right)$}

Gambar 4 menunjukkan hasil pengukuran tebal selimut yang diplot dengan tebal selimut aktual dengan variasi jarak $(s)$ dan diameter tulangan $\left(d_{b}\right)$.

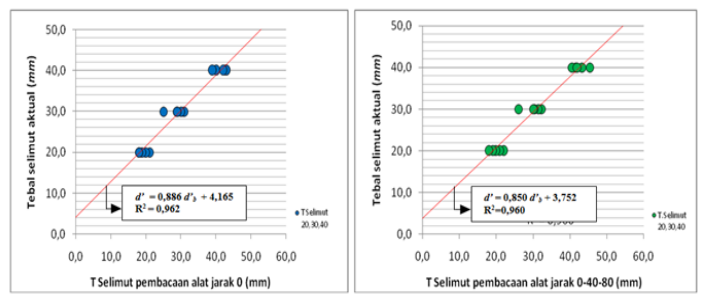

Gambar 5. Hubungan Tebal Selimut Aktual $\left(d^{\prime}{ }_{a}\right)$ dan $\left(d^{\prime}{ }_{b}\right)$ dengan Pengaruh Jarak $(s)$

Dari gambar diatas tampak bahwa semakin besar nilai $d^{\prime}{ }_{a}$ maka semakin besar pula $d^{\prime}{ }_{u}$. Model persamaan empiris dibangun untuk memprediksi tebal selimut $\left(d^{\prime}\right)$ dengan variasi diameter dan jarak tulangan (s). Persamaan (7) dan Persamaan (8) masing-masing untuk posisi tulangan tunggal dan parallel.

$$
\begin{aligned}
& d^{\prime}=0,866\left(d^{\prime}{ }_{u}\right)+4,165 \\
& d^{\prime}=0,850\left(d^{\prime}{ }_{u}\right)+3,752
\end{aligned}
$$

Pada Persamaan (7) dan (8) terlihat bahwa koefisien regresi antara nilai $d$ 'dan $d^{\prime}{ }_{u}$ menunjukkan hubungan korelasi yang kuat ditandai dengan korelasi regresi (r) masingmasing sebesar 0,962 dan 0,960. Koefisien determinasi $\left(\mathrm{r}^{2}\right)$ sebesar 0,9254 dan 0,9216 menunjukkan tingkat kesalahan prediksi sebesar $(100 \%-92,54 \%)=7,46 \%$ dan $(100 \%-92,16 \%)=$ $7,84 \%$.

\section{Aplikasi Bartracker pada Kolom}

Pengujian kolom seri $\mathrm{V}$ yang dibebani sentris sebesar $75 \%$ dari beban maksimal (beban rencana) karena keterbatasan kapasitas alat. Nilai prediksi diameter tulangan $\left(d_{b}\right)$ dan tebal selimut ( $d$ ') pada berbagai variasi kuat tekan $\left(f^{\prime}{ }_{c}\right)$ material kolom disajikan masing-masing pada Tabel 4 dan Tabel 5 berikut ini. 


\begin{tabular}{|c|c|c|c|c|c|c|c|c|c|}
\hline \multirow{3}{*}{ No } & \multirow{3}{*}{$\begin{array}{l}\text { Mutu } \\
\text { Beton }\end{array}$} & \multicolumn{3}{|c|}{ Diameter tulangan $\left(d_{b}\right)$} & \multirow{2}{*}{\multicolumn{5}{|c|}{$\%$ Tingkat Kesalahan Deteksi }} \\
\hline & & \multirow{2}{*}{ Aktual } & \multicolumn{2}{|c|}{$\begin{array}{c}\text { Prediktif } \\
\text { Rata-rata }(\mathrm{mm})\end{array}$} & & & & & \\
\hline & & & Sisi 1 & Sisi 2 & Sisi 1 & $\begin{array}{c}\text { Rata- } \\
\text { rata }\end{array}$ & Sisi 2 & $\begin{array}{c}\text { Rata- } \\
\text { rata }\end{array}$ & Rata-rata \\
\hline (1) & (2) & (3) & (4) & (5) & (6) & $(7)$ & (8) & (9) & $(10)=(7)+(9) / 2$ \\
\hline 1 & $20-0$ & \multirow{4}{*}{8} & \multirow{4}{*}{7,60} & \multirow{4}{*}{7,80} & \multirow{4}{*}{$4,99 \%$} & \multirow{12}{*}{$4,58 \%$} & \multirow{4}{*}{$6,34 \%$} & \multirow{12}{*}{$6,88 \%$} & \multirow{12}{*}{$\mathbf{5 , 7 3} \%$} \\
\hline 2 & $20-25$ & & & & & & & & \\
\hline 3 & $20-50$ & & & & & & & & \\
\hline 4 & $20-75$ & & & & & & & & \\
\hline 1 & $30-0$ & \multirow{4}{*}{8} & \multirow{4}{*}{7,78} & \multirow{4}{*}{7,86} & \multirow{4}{*}{$2,79 \%$} & & \multirow{4}{*}{$7,38 \%$} & & \\
\hline 2 & $30-25$ & & & & & & & & \\
\hline 3 & $30-50$ & & & & & & & & \\
\hline 4 & $30-75$ & & & & & & & & \\
\hline 1 & $40-0$ & \multirow{4}{*}{8} & \multirow{4}{*}{7,52} & \multirow{4}{*}{7,89} & \multirow{4}{*}{$5,97 \%$} & & \multirow{4}{*}{$6,92 \%$} & & \\
\hline 2 & $40-25$ & & & & & & & & \\
\hline 3 & $40-50$ & & & & & & & & \\
\hline 4 & $40-75$ & & & & & & & & \\
\hline
\end{tabular}

Dari Tabel 4 terlihat bahwa tidak berpengaruh signifikan adanya variasi material $\left(f_{c}^{\prime}\right)$ kolom dalam pengukuran estimasi diameter tulangan. Diameter tulangan prediktif $\left(d_{b}\right)$ lebih kecil dari diameter tulangan aktual $\left(d_{b a}\right)$ pada semua kondisi kuat tekan material kolom. Hasil analisa menunjukkan bahwa rata-rata tingkat kesalahan deteksi $d_{b}$ terhadap $d_{b}$ aktual pada sisi 1 dan sisi 2 kolom sebesar 5,73\%. Nilai ini diperkirakan disebabkan ketidaktelitian pembacaan $d_{b}$ pada posisi kolom saat dibebani dan posisi probe yang korang tepat pada posisi titik uji sebelumnya.

Rekapitulasi perolehan nilai rata-rata tebal selimut $\left(d^{\prime}\right)$ disajikan pada Tabel 5 berikut ini. Pada Tabel 5 terlihat bahwa rata-rata tingkat kesalahan deteksi tebal selimut $(d$ ') terhadap tebal selimut aktual $\left(d{ }_{a}^{\prime}\right)$ sebesar $-1,06 \%$. Tanda negative pada nilai 1,06 berati nilai prediksi lebih rendah dari nilai aktualnya. Nilai ini diperkirakan faktor ketidaktelitian ukuran ketebalan selimut saat pengecoran yang tidak seragam sebesar $26 \mathrm{~mm}$ dan juga ketidaktelitian pembacaan pada posisi sebelumnya.

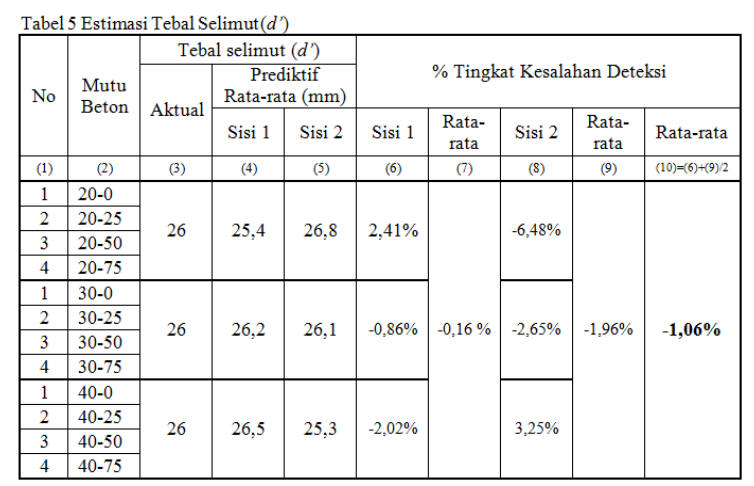

\section{Kapasitas Tahanan Penampang Kolom}

Hasil evaluasi kapasitas tahanan penampang kolom berdasarkan parameter-parameter hasil pengukuran pada tabel diatas disajikan pada Tabel 6 berikut ini.

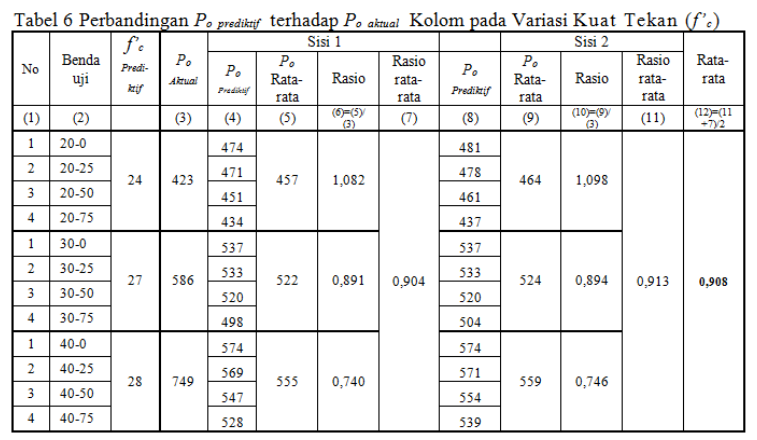

Data dari Tabel 6 diatas tampak bahwa semakin besar nilai $f_{c}$ ' semakin tinggi kapasitas tahanan $\operatorname{kolom}\left(P_{o a}\right)$. Besar $P_{o_{-} \text {prediktif }}\left(P_{o p}\right)$ lebih kecil dari $P_{o \_a k t u a l}\left(P_{o a}\right)$ dengan rasio rata-rata nilai prediktif terhadap nilai aktual sebesar 0,908 . Hal ini berarti hasil prediksi memberikan angka keamanan sebesar 1/0.908 $=1.10$.

\section{KESIMPULAN}

Berdasarkan hasil pengujian dan analisis data pada studi ini dapat diambil kesimpulan sebagai berikut :

1. Model hubungan kuat tekan $\left(f_{c}^{\prime}\right)$ dan cepat rambat gelombang $(v)$ menunjukkan bahwa semakin besar nilai $v$ semakin tinggi nilai $f_{c}^{\prime}$.

2. Model empiris yang dibangun mampu memprediksi dengan baik diameter tulangan aktual $\left(d_{b a}\right)$ dengan tingkat kesalahan prediksi $5,73 \%$ (overestimate).

3. Model empiris yang dibangun mampu memprediksi dengan baik tebal selimut aktual $\left(d_{a}^{\prime}\right)$ dengan tingkat kesalahan prediksi $-1,06 \%$ (underestimate).

4. Hasil prediksi kapasitas tahanan penampang kolom memberikan angka keamanan sebesar 1.10 .

\section{DAFTAR PUSTAKA}

Akmaluddin. 2008. Ultising NDT Aparatus for Strength Assesment of Concrete Structural Element. Rekayasa, Vol. 9 No. 2, 93-98.

Anonim. 2007a. Instruction Manual Bartracker Covermeter. Mataram: Laboratorium Struktur dan Bahan Fakultas Teknik Unram.

Anonim. 2007b. Operating Instructions PUNDITplus Model PC1006 Mataram: Laboratorium Struktur dan Bahan Fakultas Teknik Unram. 
British Standard (BS). 1988. Testing Concrete,

Recommendations on the use of Electromacnetic Covermeter.

Hariwarsianto,' M. N., 2008. Investigasi Non Destruktif dengan Profometer, Journal Teknik, Vol. 29 No. 3.

Sivasubramanian, K., Jaya., K. P., Neelemegam, M., 2013. Covermeter for Identifying Cover Depth and Rebar Diameter in High Strength Concrete, International Journal of Civil dan Structural Engineering Research, Vol. 3 No. 3.

SNI-04-1989-F. Metode Pengujian Kadar Lumpur Agregat, Pustran Balitbang PU, Jakarta.

SNI-03-1974-1990. Metode Pengujian Kuat

Tekan Beton, Badan Standarisasi Nasional.

SNI-03-2847-2002. Tata Cara Perhitungan Struktur Beton untuk Bangunan Gedung. Departemen Pekerjaan Umum.

SE-M-21-2015. Pedoman Pengukuran Ketebalan Selimut Beton dengan Covermeter Elektromagnetik. Kementerian Pekerjaan Umum dan Perumahan Rakyat. 